\title{
Development of Problem Based Learning Module for Natural Science (MIPA) Grade XI in Senior High School (SMAN 3) Kerinci
}

\author{
D Permatasari ${ }^{1 *}$ A Anhar ${ }^{2}$
}

\author{
${ }^{1}$ Biology Education, Post Graduate Program, Math and Natural Science Faculty, Universitas Negeri Padang, Padang, \\ Indonesia \\ ${ }^{2}$ Biology Department, Math and Natural Science Faculty, Universitas Negeri Padang, Padang, Indonesia \\ *Corresponding author.dwipermatasari22@gmail.com
}

\begin{abstract}
Students have difficilty in understanding the topic of respiration and excretion system because the topics are memorized, altough the topics are very close to life, so students need a module that can help them in finding concepts base on problems that are close to life. The modules had used in the school have not helped students to find concepts they need. The purpose of this development is to produce a module based on Problem Based Learning in respiration and excretion system material for high school students in XI Class.

This development uses a Plomp model. The steps are preliminary investigation, prototyping, and assessment. The research subjects are the students of XI classes in SMAN 3 Kerinci. Validation is performed by experts in biology education, education technology and Indonesian language. practicality test is done to the teacher and students,Effectiveness seen from student competencies and data was analyzed by descriptive method. The research shows that the Problem based Learning module gets a very valid category. Ans also the practicality category from the teacher and students is very good. This module has been effective in terms of student learning competencies. In this case students ' competence is increased from the specified minimum achievement. Based on these results, the conclution is the Problem based Learning module on the excretion system topic for high school students of XI Class can be declared valid, practical and effective.

Keywords: biology, effectiveness, practicality, Plomp, validation.
\end{abstract}

\section{INTRODUCTION}

Learning is essentially a process of achieving competence through a systematic learning process. The process is assistance given by educators to get the acquisition of knowledge, knowledge, skills and attitude formation on students. This learning concept is in accordance with Permendikbud No. 103 of 2014, which states that learning is a process of interaction between students and educators and learning resources in a learning environment.

The learning process in the 2013 curriculum for all levels is carried out using a scientific approach that is a learning approach that is centered on students who have the scientific approach criteria as following [1]: Learning material based on facts or phenomena that can be explained with certain logic or reasoning, logical thinking, students think critically and can apply learning material, encourage and inspire students able to think hypothetically, encourage and inspire students to develop rational thinking patterns and objective, based on concepts, theories, and empirical facts, learning objectives are formulated simply and clearly. The 2013 curriculum emphasizes the pedagogical dimension using a scientific approach. Scientific approach (scientific approach) includes observing, asking, trying, processing, presenting, concluding, and creating for all subjects [1] .

Based on the analysis of the results of the Biology teacher class XI responses in SMAN 3 Kerinci on December 6-7 Th 2018, Biology Teachers revealed that teaching materials in the learning process have not used a particular approach, learning resources rely solely on textbooks available at school, learning materials used still unable to develop scientific attitudes, students have not been actively involved in solving problems and learning materials available at school have not met the material and information needs to be needed by students..

The results of the analysis of researchers on teaching materials used by students who have been filled by 18 students of class XI MIPA 2 of SMAN 3 Kerinci, found that there are several problems regarding the implementation of learning that can be explained as follows. First, in the implementation of learning the teacher only provides teaching materials in the form of textbooks available in schools so that the supporting material in the learning process in class is inadequate with the results of the questionnaire showing $52.94 \%$. Second, teaching materials used by teachers have not been able to assist students in understanding learning material with the results of the questionnaire showing $67.70 \%$. Third, teaching materials used by teachers in the learning process 
are not yet equipped with clearer pictures and information with the results of the questionnaire showing $88.23 \%$, it can be seen from the percentage obtained that students need an update on teaching materials. Because teaching materials used by teachers in the learning process have an impact on student learning outcomes, the Minimum Completion Criteria (KKM) in Biology in Kerinci 3 High School is 70, only 9 students have grades above the KKM with a percentage of $47.36 \%$, while 10 other students scored below the KKM with a percentage of $52.64 \%$.

The textual learning process that relies on textbooks and Student Worksheets (LKPD) containing material and questions can result in teacher-centered learning, student activities are limited to solving problems in LKPD and textbooks and participants students have not been actively involved in solving problems. Learning like this tends to focus on aspects of knowledge alone, while aspects of attitudes and skills are ignored. As a result, the 2013 curriculum objectives have not been achieved optimally. Thus, it is important to develop teaching materials that can be a solution to these problems. Teaching materials that are designed systematically, completely, and attractively will affect the learning atmosphere, so that students are more motivated to learn. The use of teaching materials that are following with the demands of the 2013 Curriculum can help students achieve learning goals both knowledge, skills, attitudes and other learning experiences [2] . One of the teaching materials that can be considered is a module. Module development is needed to foster learning that is more enjoyable for students and teachers. Modules can be an attraction for students to concentrate more on learning while listening to explanations of the material presented by the teacher, the module can also train students to be more independent in learning so that they are not fixated with the teacher alone [3]. The results of the study [4] showed that the application of the use of modules significantly influenced the ability of students' science process skills. This is in line with the results of the study [5] showing that the use of modules can improve learning outcomes and there are differences in learning outcomes between students taught using modules and students taught not to use modules.

Based on the above problems, it is necessary to develop a learning module that facilitates students to have a scientific attitude using the PBL (Problem Based Learning) model, in PBL students are required to be active to get concepts that can be applied by solving problems, students will explore their concepts they must master, and students are activated to ask questions and argue through discussion, hone investigative skills, and undergo other scientific work procedures.

The existence of PBL-based modules (Problem Based Learning) may help students in achieving learning objectives, the researchers developed PBL-based modules (Problem Based Learning) which can later be used in the learning process of class XI biology, especially in the material of the respiratory system and excretion system. PBL-based modules (Problem Based Learning) present problems related to the daily lives of students, students work together with their groups in formulating existing problems, the teacher guides students in individual or group investigations, students develop and present their work and the teacher analyzes and evaluates the solution process. Has researched the development of a problembased learning device as a result of research and development obtained by a learning device with the characteristics of developing cognitive, affective, and psychomotor aspects [6]. The device is declared valid, practical and effective, because it can increase the competence of activities and motivation in learning.

Based on the background of the problem, the research about " Development of Module Based Problem Based Learning For Students of Class XI in MIPA SMAN 3 Kerinci"

\section{MATERIAL AND METHODS}

This type of research is design and development research to produce valid, practical and effective learning modules. Mendefinisikan research and development is a series of process steps in order to develop a new product or enhance existing products to be justified[7]. The study has been developed Module-Based Problem Based Learning respiratory system and excretion system for class XI MIPA 3 Kerinci.

The development of the Problem Based Learning based module uses the Plomp development model, the research stage consists of three stages: the preliminary research phase, the development or prototype phase and the assessment phase (assessment phase ) [8] .

Formative evaluation is present in all phases and repetitive cycles of research design. Formative evaluation has various layers illustrated in Figure 1.

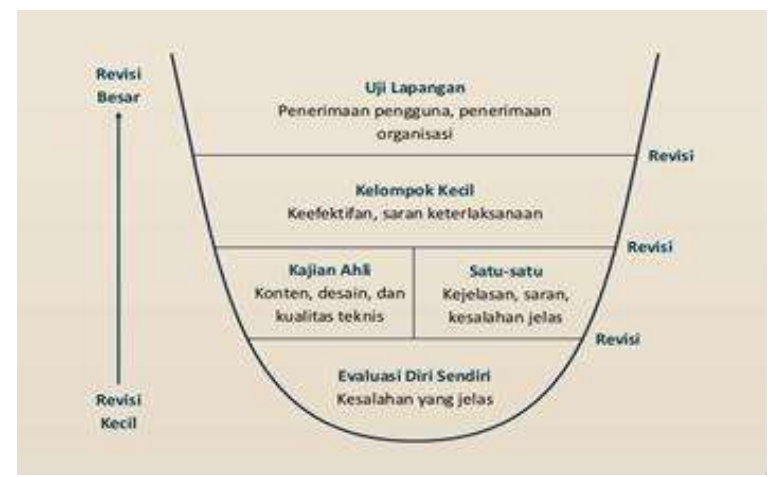

Figure 1 . Layers of Formative Evaluation [8]

The test subjects in this study were students of XI M IPA 2 SMAN 3 Kerinci Regency to find out the level of practicality and effectiveness and the data analysis technique used was descriptive analysis. Descriptive data analysis describes the validity, practicality and effectiveness of Module Based Problem Based Learning. 


\section{RESULT AND DISCUSSION}

\subsection{Result}

\subsubsection{Validity}

The modules produced in this study have been through the expert validation process with valid results and do not need to be revised. The results of the validation of the material expert, media expert, and linguist include the aspects of active, construct aspects, technical aspects are presented in Table 1 below. The overall validity of the modules can be seen in Table 1

Table 1. Overall Module Validation Results.

\begin{tabular}{|l|l|l|l|}
\hline No & Aspect & Score (\%) & Category \\
\hline 1 & Did Didtif aspect & 86.67 & Very Valid \\
\hline 2 & Construction aspects & 79.6 & Valid \\
\hline 3 & Technical aspects & 83 & Very Valid \\
\hline Average & $\mathbf{8 3 . 0 5}$ & Very Valid \\
\hline
\end{tabular}

\subsubsection{Practicality}

\section{1) Small Groups}

The small group evaluation practicality test is conducted after the one-to-one revision stage, so the module is tested on a small group of 9 students representing high, medium, and low academic abilities. Small group evaluation is limited to one meeting.

The results of the small group practicality questionnaire assessment can be seen in Tabel 2 .

Table 2. Assessment questionnaire praktialitas small groups (small gruoup)

\begin{tabular}{|c|c|c|c|}
\hline No & Aspect & Score \% & Category \\
\hline 1 & Ease of use of the module & 81.49 & $\begin{array}{l}\text { Very } \\
\text { practical }\end{array}$ \\
\hline 2 & $\begin{array}{llr}\text { The } & \begin{array}{l}\text { time required } \\
\text { in implementation }\end{array}\end{array}$ & 77.7 & Practical \\
\hline 3 & Easy to interpret & 75 & Practical \\
\hline 4 & Choose the equivalent & 77.5 & Practical \\
\hline \multicolumn{2}{|c|}{ Average } & 77.92 & Practical \\
\hline
\end{tabular}

\section{2) Large Groups}

Practicality questionnaire is given to students after participating in learning using PBL-based modules. The results of the practicality analysis of learning using PBLbased modules can be seen in Table 3. Overall the modules can be seen in Table 3 .
Table 3. Overall Module Practicality Test Results by Students

\begin{tabular}{|l|l|l|l|}
\hline No & Aspect & Score \% & Category \\
\hline 1 & Ease of Use & 81.69 & Very practical \\
\hline 2 & $\begin{array}{l}\text { The time required in } \\
\text { implementation }\end{array}$ & 89.47 & Very practical \\
\hline 3 & Easy to interpret & 82.23 & Very practical \\
\hline 4 & Choose the equivalent & 85.52 & Very practical \\
\hline Average & $\mathbf{8 4 . 7 2}$ & $\begin{array}{l}\text { Very } \\
\text { practical }\end{array}$ \\
\hline
\end{tabular}

\section{a. Effectiveness}

The effectiveness test is done to assess whether the module developed is effectively used in the learning process. The effectiveness test is done by assessing students' learning competencies in the areas of

knowledge, attitudes and skills.

1) Competency in the Domain of Knowledge

2)

Table 4. PBL-Based Module Development Test Results for Competence in the Knowledge Domain

\begin{tabular}{|c|l|l|l|l|}
\hline \multirow{2}{*}{ No } & Parameter & $\begin{array}{l}\text { Class } \\
\text { Control } \\
(\mathbf{X 1})\end{array}$ & Experiment (2) & X1> X2 \\
\hline 1 & Average & 73.53 & 85.10 & $\mathrm{X} 1<\mathrm{X} 2$ \\
\hline 2 & Normality test & 0.582 & .982 & $\begin{array}{l}\text { Normal } \\
\text { Distributed }\end{array}$ \\
\hline 3 & $\begin{array}{l}\text { Homogeneity } \\
\text { Test }\end{array}$ & 0.718 & $\begin{array}{l}\text { Homogeneous } \\
\text { Variants }\end{array}$ \\
\hline 4 & $\begin{array}{l}\text { Hypothesis } \\
\text { testing }\end{array}$ & $0.0000<1.73961$ & $\begin{array}{l}\text { H 0 is rejected, } \\
\text { H 1 is accepted }\end{array}$ \\
\hline
\end{tabular}

3) Competency in the realm of attitude

Table 5. Results of the PBL Based Module Development Hypothesis Against Competence in the Student's Attitude Domain

\begin{tabular}{|c|l|l|l|l|}
\hline \multirow{2}{*}{ No } & Parameter & Class & Information \\
\cline { 3 - 5 } & & Control & Experiment & \\
\hline 1 & Average & 80.05 & 84.27 & $\begin{array}{l}\text { Experiment } \\
\text { Control }\end{array}$ \\
\hline 2 & $\begin{array}{l}\text { Hypothesis } \\
\text { testing }\end{array}$ & $0.003<1.73961$ & $\begin{array}{l}\text { H 0 is rejected, } \\
\text { H 1 is accepted }\end{array}$ \\
\hline
\end{tabular}

4) Skills Competency

Table 6 . Hypothesis Test Results for Development of PBL- Based Modules Against Competence in the Domain of Students' Skills

\begin{tabular}{|c|l|l|l|l|}
\hline No & Parameter & \multicolumn{2}{|l|}{ Class } & Information \\
\cline { 3 - 4 } & & Control & Experiment & \\
\hline 1 & Average & 82.12 & 86,16 & $\begin{array}{l}\text { Experiment> } \\
\text { Control }\end{array}$ \\
\hline
\end{tabular}




\begin{tabular}{|l|l|l|l|}
\hline $\begin{array}{l}\text { Hypothesis } \\
\text { testing }\end{array}$ & $3,64577>1,73961$ & $\begin{array}{l}\mathrm{H} \text { 0 is rejected, } \mathrm{H} \\
1 \text { is accepted }\end{array}$ \\
\hline
\end{tabular}

\subsection{Discussion}

Validity or expert review involves three lecturers as validator expert and 2 Biology teacher as validator practically, that validation of the product can be made by $\mathrm{p}$ roots or experts who are experienced to assess new products that are designed, so it can then be known weaknesses or superiority [9] .

The problems presented in the module are real problems and problems that are presented to motivate students to think critically about problem-solving. That the main principle of PBL is the use of real problems as a suggestion for students to develop knowledge and at the same time develop critical thinking skills and problemsolving abilities [10]. This can be seen in the module why is kidney failure called a serious disease? Why kidney failure can occur? And why dialysis is one solution to kidney failure? After that, the module provides opportunities for students to work together in groups to understand the problem. Furthermore, the module facilitates students to answer questions that have been provided.

The next assessed aspect is the content aspect. Based on the results of the validation aspects of the content have been classified as very valid, as the module has loaded material by IC, BC and clear indicators. The arrangement of material is very dependent on the basic competency to be achieved. The KI developed, namely KI 3 with the description KD 3.9 analyzes the relationship between the network structure of organ building blocks in the excretion system so that it can explain the mechanisms and functional disorders that may occur in the human excretion system through literature studies, observations, experiments, and simulations [11].

The language aspect of the PBL-based module has been categorized as valid, because it is by Enhanced Spelling in Indonesian. Criteria feasibility of good language, among other things (1) the suitability of the use of language to the development of intellectual, social, and emotional reader, (2) the use of communicative language, the indicator is the legibility of the message and ordinances of the rules of language, and (3) keruntutan and alignment grooves pic i r, the indicators are complexity and cohesiveness between sections and paragraphs [12].

The graphic aspect of PBL-based modules that have been formulated has also been classified as valid, as modules are designed attractively, the purpose of designing is to display information to readers quickly, easily, and pleasantly, not vice versa [13].

Practicality for good product quality refers to the intervention (product) that is developed and is a consideration for students to use as users and makes it easy for them [8]. Practicality for the aspect of using PBLbased modules that are assessed by teachers and students is categorized as very practical because the module provides instructions in the use of clear modules. That the module must help provide instructions, stimuli, and encourage student responses, such as instructional instructions to students to understand the problem presented, students to join group friends and give instructions to students to answer questions [14].

The next assessed aspect is the aspect of presenting PBLbased modules. Based on the results of the presentation aspects which are assessed by teachers and students, the criteria are very practical. PBL-based modules on excretion system material were developed by 2013 curriculum guidelines, as students are required to be more active and one of the recommended models is PBL. The problem presented already refers to the learning objectives. A good module must have a match between the material and learning objectives [15].

The aspect assessed is the aspect of time. A good module must put time together. Based on the practical value of the aspect of time by the teacher and students can be categorized very practical. PBL-based modules help teachers and students utilize time allocation during learning [16]. Modules that will be made in PBL syntax do not include the time, preferably by including the time the learning process can run optimally and students are required to be disciplined in working on the module [17].

The effectiveness of the developed PBL -based module products are seen based on student learning competencies (knowledge, attitudes, and skills), measurement of student activities in the learning process through observation activities carried out by observers. The results obtained during the podunk trial namely, the use of PBL-based modules in the learning process has a positive impact on student learning competence. Student learning outcomes after using the PBL- based module complete category. The results of this assessment are stated to have met the KKM that has been determined by the school. Learning outcomes are categorized very effectively because of the improvement in student grades before using modules under the KKM.

Student learning outcomes after using modules increase due to the readiness of learning factors because if students learn and there is a readiness to read one of them by the module that has been read at home, the learning outcomes will be better [18]. The success of learning problem solving has a fairly high transfer, and has a retention rate that can be remembered for a long time by students [19]. Therefore, the learning outcomes achieved through the form of learning problem solving are higher in value than the benefits of learning through learning processes that take place with the presentation of learning material as occurs in conventional learning processes.

The results of the analysis of attitude competency data show that students' attitudes are obtained by effective criteria. The attitude competencies that are assessed are respect, responsibility, curiosity, and cooperation. A good PBL can encourage the development of teamwork and social skills. In the learning process, it is expected that not only knowledge competencies are mastered by students, 
but should also be accompanied by attitude competencies[20 ] .

The next competency is the competency of students' skills when practicing with a human urine test. Observations on this competency were carried out by the observer, obtained data that the competency skills of the experimental class students were better than the control class. The use of PBL

\section{CONCLUSION}

Based on expert judgment the module developed has very valid criteria. This assessment is based on 3 aspects namely, the active aspect, the construction aspect, and the technical aspects. Practicality which is assessed by students is obtained by a module with a very practical category. The effectiveness of the modules from the aspects of knowledge, attitudes, and skills is obtained that the modules developed have very effective criteria. Where the results of student competencies in the realm of knowledge, attitudes, and skills of students who use PBLbased modules are better than the learning competencies of students without using PBL-based modules.

\section{REFERENCES}

[1] Permendikbud No. 103. 2014. Learning in Primary and Secondary Education.

[2] Hamalik, Oemar. 2013. Teaching and Learning Process. Jakarta: Earth Literacy.

[3] Amelia, SER, and Suranto, AW (2016). Development of competency standard learning modules applying basic communication skills CLASS X VOCATIONAL SCHOOL, MUHAMMADIYAH 1 WATES. Journal of Office Administration Education-S1, 5 (2), 106116.

[4] Wibowo, PH, Indrowati, M., and Sugiharto, B. (2013). The Effect of Using Bentos Research Result Modules on the Subject of Environmental Pollution on Science Process Skills of Class X Students of State High School 1 Mojolaban Academic Year 2011/2012. Journal of Biological Education, 5 (1), 70-80.

[5] Abdillah, F. (2013). The Use of Modules as an Effort to Improve Student Learning Outcomes in ICT Subjects in Microsoft Word Material Class V SDN Sarikarya. Electronic Journal of Informatics Engineering Education, 1 (1).

[6] Dyahwati, P., Rahayu, ES, and Susanti, R. (2013). Development of Problem Based Learning Devices on Food Digestion System Material with Character Education Vision. Journal of Educational Research and Evaluation, 2 (1).

[7] Trianto. 2007. Integrated Learning Model. Jakarta: Literature Achievement.

[8] Plomp, T and Nieveen, N. 2013. Education Design Research: An Introduction. Enshede: models can influence student learning outcomes in psychomotor aspects.

The influence that occurs is influenced by several advantages of using problem-based learning models, namely, students can think critically, can solve problems and can experience learning directly so students will be more active and participate in learning activities than students who still use conventional learning models[21] .

SLO. Netherlands Institute for Curriculum Development.

[9] Sugiyono. 2014. Educational Research Methods Quantitative, Qualitative and $R \& D$ Approaches. Bandung: Alfabeta.

[10] Husniati, A., Suciati, S., and Maridi, M. (2016). Development of Module Based Problem Based Learning (PBL) accompanied by a Tree Diagram on Photosynthesis Material for Class VIII of SMP Negeri 1 Sawoo. Inquiry, 5 (2), 3039.

[11] Ministry of National Education. 2008. Guidelines for Development of Teaching Materials. Jakarta: Directorate General of Primary and Secondary Education Management.

[12] Muslich, M. 2007. KTSP Competency and Contextual Learning. Jakarta: Earth Literacy.

[13] Grace, Supriyono. 2010. Visual Communication Design Theories and Applications. Jogjakartai: Andi Offset.

[14] Sadiman, AS, R. Rahardjo, A. Haryono, and Rahardjito. 2006. Educational Media: Definition, Development and Utilization. Jakarta: Raja Grafindo Persada.

[15] Prastowo, A. 2011. Creative Guide to Making Innovative Teaching Materials. Yogyakarta: DIVA Press.

[16] Widjajanti, E. 2008. Quality of Student Worksheets (LKS). (Paper presented at the Community Service Seminar). Training on Chemistry Subject LKS Formulation Based on KTSP for SMK.MAK teachers on August 22, 2008). Yogyakarta: Yogyakarta State University.

[17] Raswita. 20013. Development of PBL-Oriented Learning Tools in Food Digestive System Materials in Humans for Class VIII Middle School (SMP) Students. Thesis. PPS Padang State University.

[18] Slameto, 2010. Learning and Influencing Factors. Jakarta: Rineka Cipta.

[19] Asra and Sumiati. 2007. Learning Methods. Bandung: CV. Discana Prima.

[20] Amir, M. Taufik. 2009. Educational Innovation Through Problem Based Learning. Jakarta: Kencana PM Group.

[21] Asfadi, B., Yelianti, U., \& Budiarti, RS (2014). The Effect of Problem Based Learning Model on Biology Learning Outcomes of Class X Students of SMA N 3 Jambi City. Thesis Department of Biology Education Faculty of Teacher Training and Education, University of Jambi. 
